\title{
Antimicrobial Resistance Ratios of Pseudomonas aeruginosa Strains Isolated from Various Clinical Samples-A Three- Year Evaluation
}

\begin{abstract}
Öz
Pseudomonas aeruginosa, hastane enfeksiyonlarında en sık görülen fırsatçı patojenlerden biri olup morbidite ve mortalitesi oldukça yüksektir. Bu çalışmada P.aeruginosa suşlarının antimikrobiyal direnç oranlarını belirleyerek antibiyotik kullanım politikalarına katkıda bulunulması amaçlanmıştır.

2015-2017 yıllarında çeşitli klinik örneklerden izole edilen toplam 380 P.aeruginosa suşu retrospektif olarak incelenmiştir. Gönderilen örnekler \% 5 koyun kanlı agar, Eosin Methylene Blue (EMB) agar ve çikolatamsı agar besiyerlerine, kan ve steril vücut sıvıları ise BACTEC 9120 kan kültürü sistemine ait sişelere ekilmiştir. Bakteri tanımlaması ve antimikrobiyal duyarlılık testleri için konvansiyonel yöntemler ve Phoenix tam otomatik bakteri tanımlama sistemi kullanılmıştır. Antimikrobiyal duyarlılıkları European Committee on Antimicrobial Susceptibility Testing (EUCAST) standartlarına göre yorumlanmıştır. P.aeruginosa suşlarının klinik örneklere göre dağılımı ve antimikrobiyal direnç oranları araştırılmıştır.

P.aeruginosa suşları en sık \% 47.1 oranında yoğun bakımlardan izole edilmiștir. Suşların \% 52.4'ü solunum yolu, \% 21.8'i idrar, \% 21.3'ü yara ve \% 4.4'ü de diğer örneklerden elde edilmiştir. En az direnç kolistin (\% 6.7) ve amikasine (\% 11.6) karşı bulunmuştur. Kolistin, gentamisin, seftazidim, piperasilin / tazobaktam, levofloksasin, siprofloksasin, imipenem ve meropenem için son üç yılda direnç oranlarında değişiklik olmamıştır. Sefepim ve aztreonama karşı son iki yılda direnç artışı saptanmıştır.

Çalışmada saptanan sonuçların hastane enfeksiyonlarının ampirik tedavisinde ve akılcı antibiyo-
\end{abstract} tik kullanım politikalarında katkı sağlayacağı düşünülmüştür.

Anahtar kelimeler: antibiyotik direnci, klinik örnek, Pseudomonas aeruginosa

\section{ABSTRACT}

Pseudomonas aeruginosa is one of the most common opportunistic pathogens in nosocomial infections and has quite high morbidity and mortality rates. In this study, it was aimed to determine the antimicrobial resistance rates to contribute to the antibiotic use policies.

A total of 380 P.aeruginosa strains isolated from various clinical specimens in 2015-2017 were investigated retrospectively. The samples were inoculated to $5 \%$ sheep blood agar, Eosin Methylene Blue (EMB) agar and chocolate agar media and blood-sterile body fluids were inoculated to BACTEC 9120 blood culture system. Bacterial identification and antimicrobial susceptibility tests were performed using conventional methods and Phoenix fully automated bacterial identification system. Antimicrobial susceptibilities were interpreted according to the European Committee on Antimicrobial Susceptibility Testing (EUCAST) standards. Distribution of P.aeruginosa strains according to clinical samples and antimicrobial resistance rates were investigated.

P.aeruginosa strains were most frequently isolated from intensive care units with a rate of $47.1 \%$. "The strains were obtained from the respiratory tract (52.4\%), urine (21.8\%), wound (21.3\%), and the other samples (4.4\%)." The least resistance was found aganist colistin (6.7\%) and amikacin (11.6\%). There has been no change in the resistance rates for colistin, gentamicin, ceftazidime, piperacillin / tazobactam, levofloxacin, ciprofloxacin, imipenem and meropenem in the last three years. Increased resistance to cefepime and aztreonam has been observed in the last two years.

It was thought that the results obtained in the study would contribute to empirical treatment of hospital infections and rational antibiotic use policies.

Keywords: antibiotic resistance, clinical specimens, Pseudomonas aeruginosa
Alındığı tarih: 20.05.2019

Kabul tarihi: 12.07 .2019

Yayın tarihi: 30.08 .2019

Mustafa Behçet

Bolu Abant İzzet Baysal Üniv. Tıp Fak. Tıbbi Mikrobiyoloji Anabilim Dalı Bolu-Türkiye mustafabehcet@ibu.edu.tr ORCID: 0000-0002-5676-6983

F. Avcıoğlu 0000-0002-6011-7775

S. Karabörk 0000-0002-9026-4485

M. G. Kurtoğlu 0000-0002-7057-2501 Bolu Abant İzzet Baysal Üniv. Tıp Fak. Tıbbi Mikrobiyoloji Anabilim Dalı Bolu-Türkiye

*Uluslararası XXXVIII. Türk Mikrobiyoloji Kongresi'nde sunulmuştur. PS106 (4-8 Kasım 2018, Antalya) 


\section{GiRiş}

Pseudomonas aeruginosa enfeksiyonlarının morbidite ve mortalitesi oldukça yüksek olup tüm dünyada hastane enfeksiyonlarında en sık görülen fırsatçı patojenlerden biridir. Avrupa'da 17 ülkeden 1417 yoğun bakım ünitesinde yapılan European Prevalence Infection in Intensive Care (EPIC) çalışmasında P.aeruginosa, Enterobacteriaeceae grubu ve S.aureus ile birlikte en sık izole edilen nozokomiyal enfeksiyon etkenlerinden biri olarak bildirilmiştir(8). P.aeruginosa dünya çapında nozokomiyal infeksiyonların \% 10-15'inden sorumludur(3).

P.aeruginosa, özellikle hastane ortamında bakteriyemi, menenjit, beyin apsesi, pnömoni, otit, septik artrit, osteomyelit, deri ve yumuşak doku infeksiyonları, endokardit, diyare gibi infeksiyonlara neden olan fırsatçı bir patojendir ${ }^{(18)}$.

P.aeruginosa yapısal özellikleri gereği çok çabuk direnç geliştirebilen bir bakteridir. Yanlış ve uygunsuz antibiyotik kullanımı, direnç gelişimini arttırmakta ve hastanelerdeki yoğun antibiyotik baskısı da bu dirençli suşların oluşmasına yol açmaktadır(19). Son yirmi yıl içinde dirençli P.aeruginosa suşlarının sıkığında dramatik bir artış görülmüştür. Başlangıçta duyarlı izolatların tedavi sonrasında direnç kazanması ve çoklu ilaç dirençli (MDR) izolatlarının ortaya çıkması tedaviyi daha da zorlaştırmıştır ${ }^{(17)}$. P.aeruginosa suşlarının duyarlılık oranları, çeşitli ülkelerde ve bölgeler arasında farklılık göstermektedir. Antimikrobiyal ilaçların duyarlııkları aynı hastanenin farklı bölgelerinde ve zaman içinde değişebilmektedir. Klinik örneklerden izole edilen suşların antibiyotiklere direnç durumunun bilinmesi uygun tedavi seçeneklerinin belirlenmesinde büyük önem taşımaktadır(25).

Bu çalışmada hastanemizde 2015-2017 yıllarında çeşitli klinik örneklerden izole edilen P.aeruginosa suşlarının antibiyotik direnç oranlarını saptayarak bu enfeksiyonların ampirik tedavisine ve akılcı antibiyotik kullanım politikalarına katkı sağlayacağı düşünülmüştür.

\section{GEREÇ VE YÖNTEM}

Ocak 2015-Aralık 2017 tarihleri arasında tıbbi mikrobiyoloji laboratuvarına gönderilen çeşitli klinik örneklerden izole edilen toplam 380 P.aeruginosa suşu retrospektif olarak incelenmiştir. Her hastadan üretilmiş olan tek suş çalışmaya dahil edilmiştir. Kan ve steril vücut sıvıları BACTEC 9120 kan kültürü sistemine (Becton Dickinson, $A B D$ ) ait sişelere ekilerek $37^{\circ} \mathrm{C}$ 'de en fazla yedi gün süreyle inkübe edilmiştir. Pozitif sinyal veren örneklerin tanımlamasında ve antimikrobiyal duyarlılık testlerinin saptanmasında klasik yöntemlerin yanısıra Phoenix (Becton Dickinson, $A B D$ ) tam otomatik bakteri tanımlama sistemi de kullanılmıştır. Gönderilen diğer örnekler ise \% 5 koyun kanlı, Eosin Methylene Blue (EMB) ve çikolatamsı agar (RTA, Tükiye) besiyerlerine ekilmiş olup aerobik ortamda $35^{\circ} \mathrm{C}^{\prime}$ de 24 saat inkübe edilmiştir. Antimikrobiyal duyarlılıkları klasik yöntemlerin yanısıra Phoenix (Becton Dickinson, ABD) tam otomatik bakteri tanımlama sistemiyle yapılmıştır. Antimikrobiyal duyarlılıkları European Committee on Antimicrobial Susceptibility Testing (EUCAST) standartlarına göre yorumlanmıştır ${ }^{(24)}$. P.aeruginosa suşlarının cinsiyet, gönderilen klinikler, izole edilen örneklere göre dağılımlarının yanı sıra antimikrobiyal direnç oranları da incelenmiştir. İstatistiksel analizler SPSS istatistik programı (SPSS 24.0) ile, Pearson Ki-kare testi ve yüzdelik oranlar kullanılarak yapılmıştır. Kullanılan testler için $p<0.05$ değeri istatistiksel olarak anlamlı kabul edilmiştir.

\section{BULGULAR}

Toplam 380 P.aeruginosa suşunun \% 63.2'si erkek, \% 36.8'i kadın hastalardan izole edilmiştir. Hastaların yaşları 20-93 arasında olup yaş ortalaması $66.67 \pm 15.29$ olarak saptanmıştır.

P.aeruginosa suşları en fazla oranda (\% 47.1) yoğun bakım hastalarından izole edilirken, enfeksiyon hastalıkları \% 14.2, göğüs hastalıkları \% 11.1, gastroenteroloji cerrahi \% 4.2, üroloji \% 3.9, iç hasta- 
Behçet M ve ark., Çeşitli Klinik Örneklerden İzole Edilen Pseudomonas aeruginosa Suşlarının Antimikrobiyal Direnç Oranları: Üç Yıllık Değerlendirme

Tablo. P.aeruginosa'nın antimikrobiyallere direnç oranları [dirençli sayı/test edilen sayı (\%)].

\begin{tabular}{|c|c|c|c|c|c|c|c|c|c|}
\hline \multirow{2}{*}{$\begin{array}{l}\text { Antibiyotikler } \\
\text { Kolistin* }\end{array}$} & \multicolumn{2}{|c|}{2015} & \multicolumn{2}{|c|}{2016} & \multicolumn{2}{|c|}{2017} & \multirow{2}{*}{$\begin{array}{c}p^{*} \\
0.483\end{array}$} & \multicolumn{2}{|c|}{ Toplam } \\
\hline & $5 / 111$ & $(4.5)$ & $8 / 104$ & $(7.7)$ & $7 / 82$ & $(8.5)$ & & $20 / 297$ & $(6.7)$ \\
\hline Amikasin & $19 / 150$ & $(12.7)$ & $17 / 125$ & $(13.6)$ & $8 / 105$ & $(7.6)$ & 0.320 & $44 / 380$ & (11.6) \\
\hline Gentamisin & $30 / 150$ & $(20)$ & $31 / 125$ & $(24.8)$ & $14 / 105$ & (13.3) & 0.093 & $75 / 380$ & (19.7) \\
\hline Seftazidim & $24 / 150$ & (16) & $32 / 125$ & $(25.6)$ & $26 / 105$ & $(24.8)$ & 0.101 & $82 / 380$ & (21.6) \\
\hline PTZ & $25 / 150$ & $(16.6)$ & $33 / 125$ & $(36.4)$ & $27 / 105$ & $(25.7)$ & 0.098 & $85 / 380$ & (22.4) \\
\hline Sefepim & $25 / 150$ & $(16.6)$ & $36 / 125$ & $(28.8)$ & $31 / 105$ & $(29.5)$ & 0.021 & $92 / 380$ & $(24.2)$ \\
\hline Levofloksasin & $36 / 150$ & $(24)$ & $31 / 125$ & $(24.8)$ & $30 / 105$ & $(28.6)$ & 0.694 & $97 / 380$ & (25.5) \\
\hline Siprofloksasin & $36 / 150$ & (24) & $37 / 125$ & $(29.6)$ & $31 / 105$ & $(29.5)$ & 0.493 & $104 / 380$ & $(27.4)$ \\
\hline İmipenem & $44 / 150$ & (29.3) & $46 / 125$ & (36.8) & $30 / 105$ & $(28.6)$ & 0.306 & $120 / 380$ & (31.6) \\
\hline Meropenem & $49 / 150$ & (32.7) & $44 / 125$ & $(35.2)$ & $29 / 105$ & $(27.6)$ & 0.463 & $122 / 380$ & (32.1) \\
\hline Aztreonam & $59 / 150$ & (39.3) & $89 / 125$ & $(71.2)$ & $60 / 105$ & (57.1) & 0.000 & $198 / 380$ & (54.7) \\
\hline
\end{tabular}

PTZ: Piperasilin/tazobaktam

p*: 2015-2017 yıllarında direnç oranlarının karşılaştırılması

Kolistin*: Phoenix (Becton Dickinson, ABD) tam otomatik bakteri tanımlama sistemiyle çalışılmıştır.

lıkları \% 3.4 ve diğer kliniklerden \% 16 oranında izole edilmiştir. P.aeruginosa suşlarının sıklık sırası balgam (\% 52.4), idrar (\% 21.8), yara (\% 21.3) ve diğer örnekler (\% 4.4) şeklinde saptanmıştır.

Kolistin, gentamisin, seftazidim, piperasilin / tazobaktam, levofloksasin, siprofloksasin, imipenem ve meropenem için son üç yılda direnç oranlarında değişiklik olmamıştır ( p>0.05). 2015 yılına göre 2016 ve 2017 yıllarında sefepim ( $p=0.021$ ) ve aztreonama $(p=0.000)$ karşı son iki yılda direnç artışı saptanmıştır. Hastanemizde P.aeruginosa'da en az direnç kolistine karşı gözlenmiştir. 2015 yılında \% 4.5 olan direnç oranı, 2016 yılında \%7.7 ve 2017 yılında \% 8.5'e yükselmesine rağmen istatistiksel olarak anlamlı bulunmamıştır ( $p=0.483)$. Sırasıyla en az direnç gözlenen ikinci ve üçüncü antibiyotikler olan amikasine $(p=0.320)$ ve gentamisine $(p=0.093)$ karşı $2015(\%$ 12.7, \% 20) ve 2016 (\% 13.6, \% 24.8) yıllarına göre 2017 (\% 7.6, \% 13.3) yılında gözlenen direnç oranlarındaki düşüş istatistiksel olarak anlamlı bulunmamıştır. Sırasıyla piperasilin / tazobaktam ve seftazidime karşı 2015 (\% 16.6, \% 16) yılına göre 2016 (\% 36.4, \% 25.6) ve 2017 (\% 25.7,\% 24.8) yıllarında görülen direnç oranlarındaki artış istatistiksel olarak anlamlı bulunmamıştır. P.aeruginosa'nın yıllara göre antimikrobiyallere direnç oranları Tablo'da verilmiştir.

\section{TARTIŞMA}

P.aeruginosa daha çok hastane enfeksiyonu şeklinde olmak üzere, immün yetmezliği, malign veya metabolik hastalığı olanlarda, yaşlılarda, ağır yanıklı kişilerde, uzun süre kemoterapi-radyoterapi alanlarda en önemli enfeksiyon etkenlerinden biridir $^{(20)}$. Ülkemizde yapılan bazı çalışmalarda P.aeruginosa değişik oranlarda olmakla birlikte en sık yoğun bakımlardan (\% 43-88.3) izole edilmiştir ${ }^{(8,14)}$. $\mathrm{Bu}$ çalışmalarla uyumlu olarak çalışmamızda da P.aeruginosa en sık yoğun bakımlardan (\% 47.1) izole edilmiştir.

Solunum yolu örnekleri Pseudomonas izolatlarının en sık kaynağı olup bunu yara, idrar ve kan örnekleri izlemektedir ${ }^{(5)}$. Ülkemizde (\% 16-56.7) ve yurtdışında (\% 38-60.99) yapılan bazı çalışmalarda olduğu gibi çalışmamızda da (\% 52.4) P.aeruginosa en sık solunum yolu örneklerinden izole edilmiştir ${ }^{(1,6,13,22,25,27)}$.

P.aeruginosa farklı mekanizmalarla antibiyotiklere karşı direnç geliştirmektedir. Beta-laktam antibiyotiklere karşı direnç gelişimi Amp C tipi betalaktamaz sentezlenmesi, genişlemiş spektrumlu beta-laktamazlar, karbapenemazlar, dış membran geçirgenliğinde azalma ve aktif dışa pompalama mekanizmaları şeklindedir. Aminoglikozid değiştirici enzimlerle aminoglikozidlere, DNA giraz-enzim mutasyonlarıyla kinolonlara direnç kazandıkları bilinmekte- 
dir. Ayrıca birkaç direnç mekanizmasının birlikte görüldüğü çoğul dirençli suşlar P.aeruginosa'da yaygındır ${ }^{(7)}$.

P.aeruginosa için beta laktam antibiyotikler ile ilgili değişik direnç oranlarına rastlanmaktadır. Ülkemizde yapılan çalışmalarda piperasilin / tazobaktam için \% 15.4-71, seftazidim için \% 23.5-42, sefepim için \% 24.6-45.8, imipenem için \% 23.8-61.2, meropenem için 24.6-54.1 ve aztreonam için \% 55 direnç oranları bildirilmiştir ${ }^{(2,4,6,9,11,12,15,23,25,29)}$.

Yurtdışında yapılan çalışmalarda piperasilin / tazobaktam için \% 7-38.5, seftazidim için \% 15.7-58.0, sefepim için \% 14.6-52.5, imipenem için \% 8.6-20.8, meropenem için \% 6.2-6.5 ve aztreonam için \% 36.3 direnç oranları bildirilmiştir ${ }^{(1,13,21,22,28)}$. ABD, Fransa, Almanya, İtalya ve İspanya'da yapılan ortak bir çalışmada sefalosporinlere karşı direnç oranı \% 18.6-40.5, karbapenemlere karşı \% 21-52.7 ve beta-laktamaz inhibitörlerine karşı \% 55.8-79.5 gibi yüksek direnç oranları saptanmıştır ${ }^{(16)}$. Yapılan bu çalışmalarda farkIı direnç oranları bildirilmiş olmakla birlikte çalışmamızda seftazidim için saptadığımız \% 21.6, piperasilin/tazobaktam için \% 22.4, sefepim için \% 24.2, imipenem için \% 31.6, meropenem için \% 32.1 ve aztreonam için \% 54.7'lik direnç oranları ülkemizde ve yurt dışında yapılan bir çok çalışmayla uyumluluk göstermiştir ${ }^{(2-4,6,9,11,16,21-23,25,29)}$. Çalışmamızda piperasilin / tazobaktam ve seftazidime karşı 2015 yılına göre 2016 ve 2017 yıllarında görülen direnç oranlarındaki artışlar istatistiksel olarak anlamlı bulunmazken ( $p>0.05$ ) sefepim ve aztreonama karşı 2015 yılına oranla 2016 ve 2017 yıllarında direnç artışı saptanmıştır $(p=0.021)$. Direnç oranlarındaki farklılıkların, hastanelerde uygulanan farklı antibiyotik kullanım politikaları ve yoğun bakım ya da hastanede uzun süre yatma gibi nedenlerden kaynaklanabileceği düşünülmüştür.

Pseudomonas tedavisinde kullanılan bir diğer grup antibiyotik kinolonlardır. Ülkemizde yapılan bazı çalışmalarda siprofloksasin için direnç oranı \% 19.745.9, levofloksasin için \% 23.8-52, yurtdışında yapılan çalışmalarda siprofloksasin için direnç oranı \% 22.5-49 levofloksasin için \% 16.5-26.7 olarak bildirilmiştir $^{(1,2,4,4,6,9,11,12,15,21-23,25,28,29)}$. Çalışmamızdaki kinoIon grubu ilaçlara karşı son üç yılda direnç oranların- da herhangi bir değişiklik gözlenmemiş olup ( $p>0.05$ ) siprofloksasin için saptadığımız \% 27.4 ve levofloksasin için \% 25.5'lik direnç oranı bu çalışmalardaki direnç oranlarıyla benzerlik göstermiştir.

Aminoglikozid grubundan amikasin, modifiye edici enzimlerden daha az etkilendiği için grubun diğer üyelerine kıyasla daha nadir direnç gelişmektedir(10). Ülkemizde yapılan bazı çalışmalarda amikasin için direnç \% 9-43, gentamisin için \% 17.2-75 olarak bildirilirken yurt dışında yapılan çalışmalarda amikasin için direnç \% 3-16.7 ve gentamisin için $\%$ 13.5-47 oranlarında bulunmuştur ${ }^{(1,2,2,4,6,9,12,13,15,22,23,25,28)}$. Çalışmamızda amikasine $(p=0.320)$ ve gentamisine ( $p=0.093)$ karşı 2015 ve 2016 yıllarına göre 2017 yılında gözlenen direnç oranlarındaki düşüş istatistiksel olarak anlamlı olmayıp amikasin için saptadığımız \% 11.6 ve gentamisin için \% 19.7'lik direnç oranları Akduman Alaşehir ve ark.'nın ${ }^{(2)}$ amikasin için bildirdiği \% 9.8 ve gentamisin için \% 17.2'lik direnç oranlarıyla yakın benzerlik göstermektedir. Hindistan'da yapılan bir çalışmada amikasin için \% 25.5 , gentamisin için \% 71.9 gibi yüksek oranlarda direnç saptanmıştır ${ }^{(21)}$.

Kolistin kullanımının artması, dünya çapında kolistin direncinin ortaya çıkmasına yol açmıştır. Direnç oranları genellikle \% 10 'un altında olsa da bir artış eğilimi gözlenmektedir. Kolistine duyarlılık testlerinde en önemli güçlük duyarlılığın belirlenmesindeki sorunlardır. CLSI (Clinical and Laboratory Standards Institute)-EUCAST polimiksin eşik değer belirleme çalışma grubu, ISO 20776 standardı gereğince kolistin duyarlılığının belirlenmesi için sıvı mikrodilüsyon yöntemini "referans yöntem" olarak belirlemiştir(26). Çalışmamızda kolistin duyarlılığı için tam otomatik bakteri tanımlama sistemi kullanılmıştır. Kolistin duyarlılığının sıvı mikrodilüsyon yöntemiyle çalışıımaması çalışmamızın kısıtılııı̆̆ıdır. Çalışmamızda istatistiksel olarak anlamlı olmamakla birlikte kolistine karşı direnç oranları artma eğiliminde olup saptadığımız \% 6.7 oranındaki kolistin direnci ülkemizde otomatize sistemlerle yapılan benzer çalışmalarla (\% 0-7) uyumlu bulunmuştur ${ }^{(9,14,25,29)}$.

Sonuç olarak çalışmamızda en az direnç kolistin (\% 6.7) ve amikasin (\% 11.6) için saptanmıştır. 
Behçet M ve ark., Çeşitli Klinik Örneklerden İzole Edilen Pseudomonas aeruginosa Suşlarının Antimikrobiyal Direnç Oranları: Üç Yıllık Değerlendirme

Hastanemizde antibiyotik direnç oranlarında son iki yılda sefepim ve aztreonam dışında diğer antibiyotiklerde bir artış saptanmamıştır. Antibiyotik duyarlılığının coğrafik bölgelere ve hastanelere göre yıldan yıla değişebileceği göz önünde bulundurularak her merkezin kendi antibiyotik duyarlılık profillerini güncelleyerek ampirik tedavide ve antibiyotik kullanım politikalarına katkıda bulunacağı kanaatindeyiz.

Çıkar Çatışması: Yazarlar tarafından herhangi bir çıkar çatışması bildirilmemiştir.

Conflict of Interest: No conflict of interest was declared by the authors.

\section{KAYNAKLAR}

1. Ahmed OB. Incidence and antibiotic susceptibility pattern of Pseudomonas aeruginosa Isolated from Inpatients in two tertiary hospitals. Clin Microbiol. 2016;5(2):2-4.

2. Akduman Alaşehir E, Karadeniz A, Balıkçı A, Topkaya E. Klinik örneklerinden izole edilen Pseudomonas aeruginosa suşlarının antibiyotik duyarlılıkları. Maltepe Medical Journal. 2013:5(3):12-6.

3. Aktaş E, Terzi HA, Külah C, Cömert F. Pseudomonas aeruginosa izolatlarının antibiyotik duyarlılıklarının değerlendirmesi: çeşitli antibiyotiklere azalan duyarlılık. ANKEM Derg. 2010;24(4):188-92.

4. Berktaş M, Çıkman A, Parlak M, Yaman G, Güdücüoğlu H. Nozokomiyal kökenli Pseudomonas aeruginosa izolatlarında antibiyotiklere direnç. Van Tıp Derg. 2011;18(4):192-6.

5. Brusselaers $\mathrm{N}$, Vogelaers $\mathrm{D}$, Blot $\mathrm{S}$. The rising problem of antimicrobial resistance in the intensive care unit. Ann Intensive Care. 2011;1(1):47-53. https://doi.org/10.1186/2110-5820-1-47

6. Calgin MK, Cetinkol Y. Assessment of antibiotic resistance rates of Pseudomonas aeruginosa and Acinetobacter baumannii strains isolated in intensive care units between 2014 and 2017. Annals of Medical Research. 2019;26(2):213-6. https://doi.org/10.5455/annalsmedres.2018.09.186

7. Coşkun USŞ, Coşkun G. Klinik örneklerden izole edilen Pseudomonas aeruginosa suşlarının antibiyotik direnç durumunun belirlenmesi. FLORA. 2013;18(4):175-80.

8. Duman Y, Kuzucu Ç, Kaysadu H, Tekerekoğlu MS. Bir yıllık sürede izole edilen Pseudomonas aeruginosa suşlarının antibiyotik duyarlılığının araştırılması: kesitsel bir çalışma. İnönü Üniversitesi Sağlık Bilimleri Derg. 2012;1(1):41-5.

9. Durmaz S, Toka Özer T. Klinik örneklerden izole edilen Pseudomonas aeruginosa suşlarında antibiyotik direnci. Abant Tıp Derg. 2015;4(3):239-42. https://doi.org/10.5505/abantmedj.2015.38981

10. Dursun A, Özsoylu S, Kılıç H, Kılıç AU, Akyıldız BN. Çocuk yoğun bakım ünitesinde yatan hastalardan izole edilen Pseudomonas aeruginosa, Klebsiella pneumoniae ve Acinetobacter baumannii suşlarının antibiyotik duyarlılıkları. Turk J Intensive Care. 2018;16(3):109-14.

11. Ekincioğlu P, Perçin D. Klinik Pseudomonas aeruginosa izolatlarının antibiyotiklere duyarlılık durumu. Sağlık Bilimleri Derg. 2013;22(2):141-9.

12. Gültepe B, Iraz M, Ceylan A, Doymaz MZ. Çeşitli Klinik örneklerden izole edilen Pseudomonas suşlarının antibiyotiklere direnci. ANKEM Derg. 2014;28(1):32-6 https://doi.org/10.5222/ankem.2014.032

13. Juayang A, Lim J, Bonifacio A, Lambot A, Millan $S$, Sevilla V, Sy J, et al. Five-year antimicrobial susceptibility of Pseudomonas aeruginosa from a local tertiary hospital in Bacolod City, Philippines. Trop Med Infect Dis. 2017;2(3):28-35. https://doi.org/10.3390/tropicalmed2030028

14. Karakeçe E, Terzi HA. Çiftci iH. Pseudomonas aeruginosa izolatlarının antibiyotik duyarlılıklarının değerlendirmesi. Medeniyet Medical Journal. 2014;29(1):20-3.

15. Köse Ş, Atalay S, Ödemiş I, Adar P. Çeşitli Klinik örneklerden izole edilen Pseudomonas suşlarının antibiyotik duyarlılıkları. ANKEM Derg. 2014;28(3): 100-4.

https://doi.org/10.5222/ankem.2014.100

16. Micek ST, Wunderink RG, Kollef $\mathrm{MH}$, et al. An international multicenter retrospective study of Pseudomonas aeruginosa nosocomial pneumonia: impact of multidrug resistance. Crit Care. 2015;19(1):219-26. https://doi.org/10.1186/s13054-015-0926-5

17. Nathwani D, Raman G, Sulham K, Gavaghan M, Menon V. Clinical and economic consequences of hospital-acquired resistant and multidrug-resistant Pseudomonas aeruginosa infections: a systematic review and meta-analysis. Antimicrob Resist Infect Control. 2014;3(1):32-48. https://doi.org/10.1186/2047-2994-3-32

18. Öztürk CE, Çalışkan E, Şahin i. Pseudomonas aeruginosa suşlarında antibiyotik direnci ve metallo beta-laktamaz sıklığı. ANKEM Derg. 2011;25(1):42-7. https://doi.org/10.5222/ankem.2011.42

19. Öztürk $\mathrm{CE}$, Türkmen Albayrak $\mathrm{H}$, Altınöz $\mathrm{A}$, Ankaralı 
H. Pseudomonas aeruginosa suşlarında antibiyotiklere direnç ve beta-laktamaz oranları. ANKEM Derg. 2010;24(3):117-23.

20. Paköz NiE, Şeriban Doğan S, Aral M. Çeşitli klinik örneklerden izole edilen Pseudomonas suşlarının antibiyotiklere duyarlılıkları. ANKEM Derg. 2011;25(2):73-8.

https://doi.org/10.5222/ankem.2011.073

21. Raakhee T, Rao US. Prevalence and resistance pattern of pseudomonas strains isolated from ICU patients. Int J Curr Microbiol App Sci. 2014;3:527-34.

22. Sader HS, Huband MD, Castanheira M, Flamm RK. Pseudomonas aeruginosa antimicrobial susceptibility results from four years (2012 to 2015) of the international network for optimal resistance monitoring program in the United States. Antimicrob Agents Chemother. 2017;61(3):e02252-16. https://doi.org/10.1128/AAC.02252-16

23. Taşbent FE, Doğan M, Feyzioğlu B, Baykan M. Çeşitli Klinik örneklerden izole edilen Pseudomonas türlerinin antibiyotiklere direnci. Türk Mikrobiyol Cem Derg. 2013;43(4):138-43.

24. The European Committee on Antimicrobial Susceptibility Testing. Breakpoint tables for interpretation of MICs and zone diameters. Version
4.0, (2014).

25. Tümer S, Kirişci Ö, Özkaya E, Çalışkan A. Çeşitli klinik örneklerden izole edilen Pseudomonas aeruginosa suşlarının antibiyotik duyarlılıkları. ANKEM Derg. 2015;29(3):99-104.

26. Tüzemen NÜ, Efe K, Akalın H, Özakın C. Retrospective evaluation of colistin-resistant isolates in automated system by gradient diffusion method and broth microdilution method. Klimik Derg. 2019;32(1):5761. https://doi.org/10.5152/kd.2019.13

27. Vojtová V, Kolár M, Hricová K, Uvízl R, Neiser J, Blahut L, Urbánek K. Antibiotic utilization and Pseudomonas aeruginosa resistance in intensive care units. New Microbiologica. 2011;34(3):291-8.

28. Yadav VC, Kiran VR, Jaiswal MK, Singh K. A study of antibiotic sensitivity pattern of Pseudomonas aeruginosa isolated from a tertiary care hospital in South Chhattisgarh. International Journal of Medical Science and Public Health. 2017;6(3):600-6. https://doi.org/10.5455/ijmsph.2017.0956717102016

29. Yapıcı O, Akgüneş A, Akgül S, Ekinci B, Pekintürk NS. Pseudomonas aeruginosa suşlarının direnç durumunun yıllar içindeki değişimi. Muğla Sıtkı Koçman Üniversitesi Tıp Derg. 2018;5(1):1-4. 